\title{
SAFETY ASSESSMENT OF EXISTING POST-WAR REINFORCED CONCRETE BRIDGES. THE CASE STUDY OF 'GERBER GIRDERS' BRIDGES IN ITALY
}

\author{
I. GIANNETTI ${ }^{*}$, S. MORNATI ${ }^{1}$, S. COCCIA ${ }^{1}$, F. DI CARLO $^{1}$ AND Z. RINALDI $^{1}$ \\ ${ }^{1}$ Department of Civil Engineering and Computer Science Engineering (DICII) \\ University of Rome "Tor Vergata" \\ 1 Via del Politecnico, 00133 Rome, Italy \\ e-mail: \{coccia, di.carlo, mornati, rinaldi\}@ing.uniroma2.it \\ * Department of Civil Engineering and Computer Science Engineering (DICII) \\ University of Rome "Tor Vergata" \\ 1 Via del Politecnico, 00133 Rome, Italy \\ e-mail: ilaria.giannetti@uniroma2.it (*corresponding author)
}

Keywords: $20^{\text {th }}$ century heritage, reinforced concrete bridges, safety assessments, construction history, Italy

\begin{abstract}
The interest in the structural maintenance design of existing bridges of the Italian road network is nowadays growing, due to the need to overcome structural inadequacies and/or degradation phenomena. In this framework, the new "Guide-lines for risk management, safety assessment and monitoring of existing bridges" outline the required procedures and tools, identifying the most critical issues of the different bridges' structural typologies, including Gerber girders in reinforced concrete bridges. A safety assessment of Gerber bridges is thus mandatory as for the presence of joints which do not comply with current design practice and codes as for the occurrence of aging-related decay phenomena, e.g. due to water infiltration. In this context, a novel cross-disciplinary procedure for the assessment of Gerber bridges is here presented, giving an insight on the so-called 'knowledge phase'. Firstly, the paper analyses the introduction and diffusion of this structural typology in Italy, giving a classification of existing Gerber bridges and focusing on their recurrent degradation phenomena. Finally, a discussion on historical sources which can be used to draw useful information, e.g. construction history surveys, archival drawings, calculation manuals and codes, is presented.
\end{abstract}

\section{INTRODUCTION}

In Europe, during the 1950s and 1970s the wide development of roads and highways network led to the fast construction of a wide stock of reinforced concrete bridges. Alongside the development of the typology of the arch bridge, the diffusion of girders bridges was supported by the adaptation, from the 1930s onwards, of the Gerber scheme to reinforced concrete bridges. Concerning the half-joint design, building code and calculation methods of the time led to reinforcements arrangement solutions that today, following the calculation theory evolution, are considered improper for the actual structural task $[1,2]$ : as a 
consequence, the whole stock of existing Gerber truss bridges of the Italian road network exhibits insufficient performance in terms of structural safety, representing an urgent task for the structural maintenance design.

On May 6th, 2020 the Italian National Ministry of Infrastructures and Transports approved the new "Guide-lines for risk management, safety assessment and monitoring of existing bridges" [3]. In addition to the procedures and the tools to respond to the general purposes of this document, it identifies critical issues related to different bridge structural typologies.

In particular, a detailed classification of "critical elements" (i.e. those bridge parts that are particularly subject to degradation phenomena and whose possible malfunctions can significantly affect the overall structural behaviour of the structure) was provided. These elements include Gerber girders in reinforced concrete bridges, requiring a mandatory and urgent general safety assessment of the structure of Gerber bridges.

If, from the one hand, internal steel reinforcement layouts of the Gerber joints do not comply with current design practice and codes, from the other, Gerber joints are difficult to inspect and, due to their shape, they are particularly subject to water infiltration.

Moreover, the Guidelines highlight the importance of "an accurate investigation of the technical and administrative documentation of the existing bridges" [3], in order to acquire the knowledge necessary for any conservation project, regarding both the adopted design and construction procedures, as well as the transformations of works over the years of their functioning. From the cited document, on the one hand, the importance of the role of the historical research in the monitoring and preservation projects of existing bridges emerges and, on the other hand, the urgency to focus the anatysis on reinforced concrete "Gerber
bridges" that still exist in the Italian national territory.
In this code framework, the proposed paper presents a novel cross-disciplinary procedure
for the performance analysis. According to the actual flowchart in the assessinent andlysis,
composed of the two steps of the 'knowledge phase' and the analysis phase', the proposed procedure gives an insight on the 'knowledge phase' through construction history surveys, in

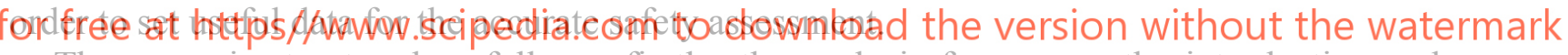

The paper is structured as follows: firstly, the analysis focuses on the introduction and diffusion of this structural typology in Italy and on the list and classification of existing Gerber bridges alongside their recurrent degradation phenomena; then, the historical sources typologies are discussed, focusing archival drawings and calculation manuals and codes.

\section{THE GERBER BRIDGE}

The progressive introduction of the static scheme of the cantilever beam (cantilever bridges) was developed with the intention of transforming the continuous beam on several supports into a statically determined system, through the introduction of a strictly indispensable number of hinges. In fact, this solution permitted simplification of calculations, optimisation of stresses on the structural elements, compensation of vertical failure whilst developing construction processes without falsework.

The scheme of the cantilever bridge, which had been systematically developed in the nineteenth century, with the rise of iron and steel as construction materials, dates back to ancient times $[4,5]$. As noted in the literature [4,6-9], the development and systematization of this bridge typology took place in the second half of the 19th century. Between the 1940s and 
the 1960s several engineers (Fairbairn, Clark, Ritter, Culmann) tried their hand at the subject, obtaining substantial theoretical and design solutions. The scheme, already known as a cantilever bridge, portes à faux in French, took the name 'Gerber girders', from the German engineer Heinrich Gerber (1832-1912), in the 1860s. Although it was not always mentioned in the treatises of the time [9], Gerber was nonetheless recognized as the author of the first bridge built with this static scheme. It was the bridge over the Main in Hassfurt (1867), in which the central span beam was placed on the two lateral cantilevered beams, by hinge joints. The static solution was repeated the same year in the Sofia Bridge in Bamberg. The system was patented in 1866 [10] (Fig. 1).

In 1877, Charles Shaler Smith (1836-1886) built the Kentucky Viaduct, the first large span cantilever bridge in America: in this structure and, in the subsequent Niagara Viaduct, built in 1883 by Charles Conrad Schneider (1843-1916), the assembly of the beam without fixed scaffolding was adopted. The names of the two American viaducts identified the types that classify the construction procedures without false works, which were later adopted for the construction of structures of this type. In 1889, the opening of the Forth Bridge on the Firth of Forth, by John Fowler (1817-1898) and Benjamin Baker (1840-1907), marked the end of the experimental period of this structural typology and its definitive systematization for large span metal truss bridges.
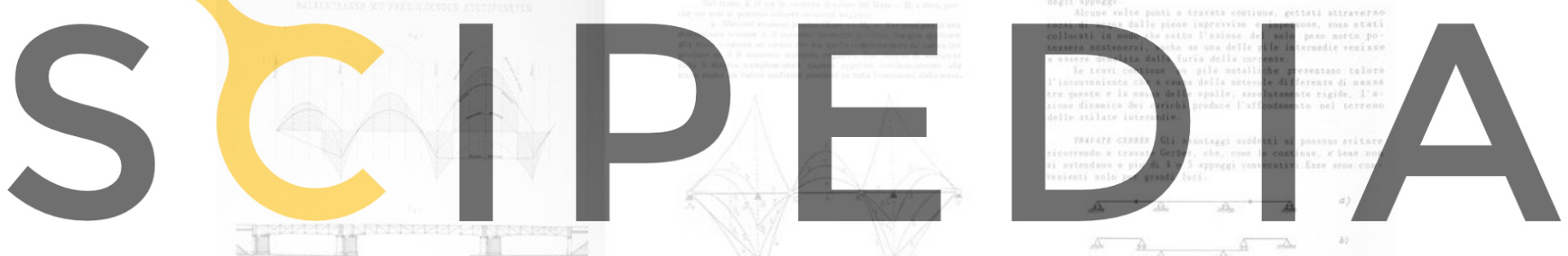

Register for free at https//www.scipedia.com to download the version without the watermark
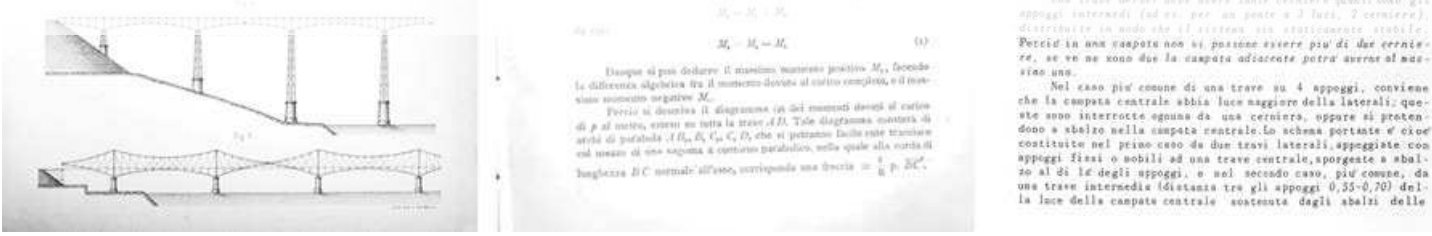

Figure 1: Gerber patent, 1866 [10] and Italian bridge design manuals [11, 19]

\subsection{Introduction in Italy}

In Italy the 'Gerber bridge', entered engineering practice late; this was testified by the wellknown and widespread Manual of the Engineer [11] edited by engineer Giuseppe Colombo (1836-1921) from the first edition of 1877 to 1917; still, in the 1926 edition of this Manual, the Gerber beam was not included in the chapter dedicated to structural schemes.

In 1905, Antonio F. Jorini (1853-1931) dedicated chapter VI of his manual "Theory and Practice of Bridge Construction" to "continuous beams with hinges" [12]. The bibliographical references at the bottom, all foreign, suggest that this text was the first published in Italy on 
the subject. In the manual, where the calculation of a three-span beam, with two hinges in the central span, was illustrated, the convenience of introducing hinges into the continuous beam schemes was defined because "with the choice of the number of hinges, and their position in the continuous beam, it is possible to obtain a statically determined structure, in which the internal stresses are independent of the vertical movements of the supports" [12].

In Italy, given the limited development of large span metal viaducts at the end of the nineteenth century when compared to other industrialized countries, the spread of Gerber-type bridges was directly due to the introduction of reinforced concrete.

In 1930, Giuseppe Albenga (1882-1957) in chapter V of his book Lessons of Bridges reported the convenience of adopting hinged patterns in continuous reinforced concrete trusses. "Introducing as many hinges as there are superabundant support conditions", with the warning "not to drop more than two hinges between two consecutive supports and not to have more than two supports between two successive hinges" [13]. In the Manual, there are no examples of "Gerber bridges" in reinforced concrete built in Italy, but the "very frequent use in reclamation areas" of cantilevered beams is mentioned, in particular for "three-span schemes characterized by two intermediate piers and small cantilevered bank spans" [13]. On the other hand, not even the two editions, published in 1924 and 1932 respectively, of the "Ponti in cemento armato Italiani" manual by G. Santarella and E. Miozzi, reported built examples of 'Gerber bridges' $[14,15]$.

In 1933, the catalogue of the Ferrobeton firm [16], at the time one of the main Italian companies active in the

of the following bridges

in Calabria; the bridge

Capua designed by the

Only in 1953 , when
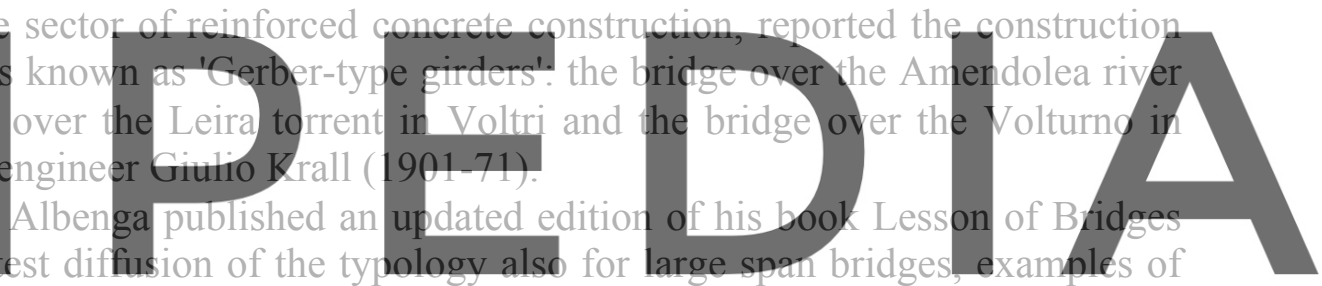

reinforced concrete Gerber bridges built in Italy were cited: the bridge of the Empire over the

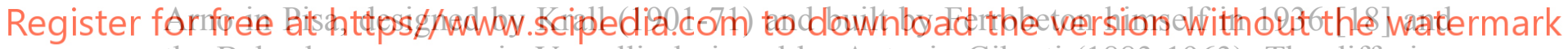
the Belvedere overpass in Vercelli, designed by Antonio Giberti (1883-1963). The diffusion of the typology was also testified by the updated edition of the same Albenga manual, dedicated instead to theory [19]: the third chapter was entitled "the simple beam and the Gerber beam", testifying the diffusion of the latter structural typology for reinforced concrete buildings. In 1974, Giuseppe Rinaldi in his manual "The construction of bridges" [20] reported a series of economic considerations on the use of different types of reinforced concrete bridges, in the light of the development of the freeway network (1956-73): even if "recently works of this type have been carried out with positive results", there was an overall decrease in the application of the scheme. The Gerber scheme, considered more suitable for casting, was considered ideal for spans within 65 meters and "limited for higher spans by the costs of centering" [20].

\subsection{For a census of the existing reinforced concrete Gerber bridges in Italy}

From a first survey on the Italian territory road bridges, the existing reinforced concrete 'Gerber bridges' were mostly built between the 1930s and 1970s, in particular according to 
the urgency of the reconstruction after WWII and the development of the national road network between the 1950s and 1960s.

These structures feature a remarkable shape variety and can be classified according to the three static schemes represented in Figure 2. The first scheme represents an articulated girder with multiple supports: considering the general principle that a Gerber girder must have as many hinges as there are intermediate supports and that these hinges must be placed in order to ensure the stability of the system, an articulated girder is placed between the two overhangs (internal hinge - Niagara Type) or between the central piers and the abutments (external hinge - Kentucky type) (Fig. 2a). The second diagram describes a sequence of cantilevered piers and suspended span (Fig. 2b). The third scheme describes a sequence of multiple statically determinate frames (Fig. 2c).
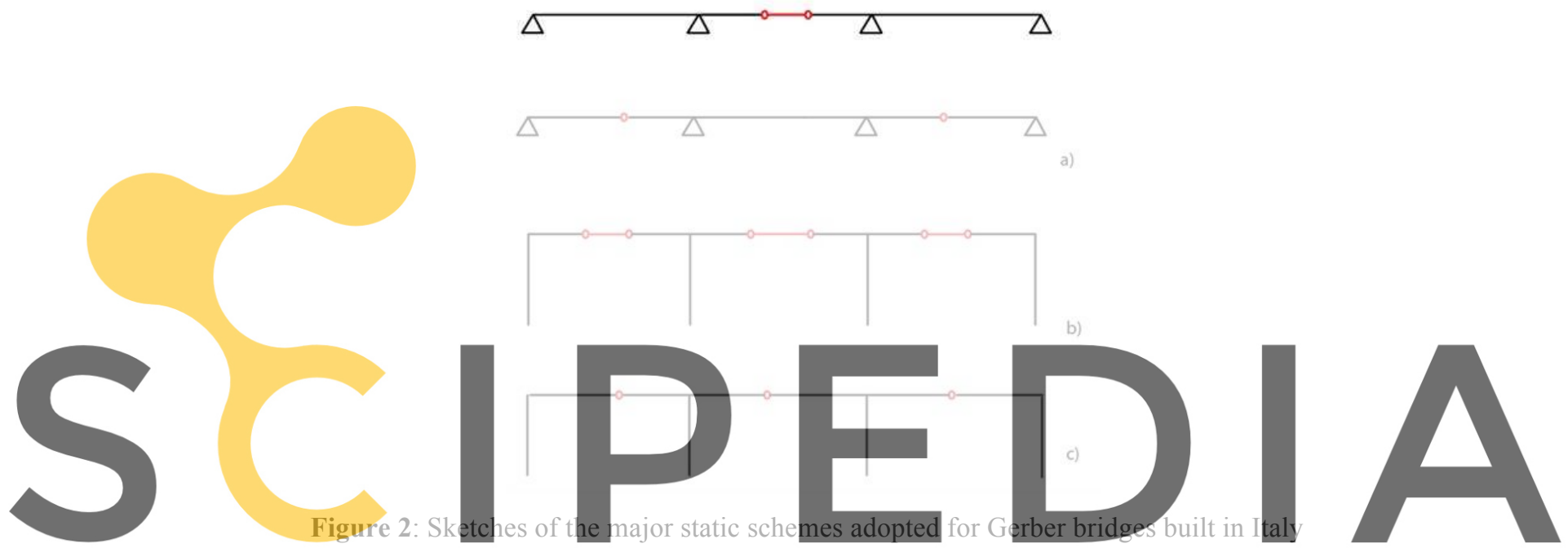

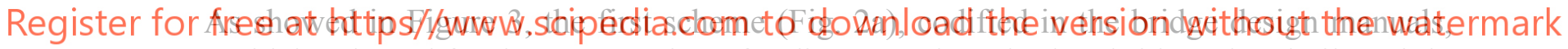
was widely adopted for the construction of ordinary roads and urban bridges that, built mainly between the 1930s and the 1950s, were featured by the exclusive use of cast in situ reinforced concrete. Some significant examples were among the first bridges featuring this static scheme: the aforementioned bridge over the Arno river in Pisa, rebuilt by the same construction company Ferrobeton in 1947 after the WWII; the Magliana bridge over the river Tiber in Rome (1938) and the Marconi bridge over the rives Tiber in Rome (1939).

The second scheme (Fig. 2b) was mainly used for the construction of highway bridges built in the 1950s and 1960s. Also taking advantage of the greater diffusion of industrialization in the building sector and of the pre-stressing technique in reinforced concrete construction, these bridges feature prefabricated suspended spans and cast in situ cantilevered piers. Noteworthy examples of this typology are: both the Rio Sanda bridge over the Teiro bridge on the Voltri-Albissola highway (1955) and the Settefonti viaduct of the Autostrada del Sole highway (1959); the Colle Isarco viaduct for the Brennero highway (1962), characterized, instead, by the combined use of the cantilever construction technique, pre-stressing systems and prefabricated elements [21]. On developing the same optimization goal of the execution, avoiding falsework, the third scheme (Fig. 2c) representing a sequence of multiple statically determinate frame was in the viaducts designed by engineer Silvano 
Zorzi (1921-94). Between them, noteworthy examples are the Stura viaduct of the TurinSavona highway (1968-70) [22] and the Poala viaduct at Veglio Mosso (1972-73) [23]. If, from the construction site point of view, the adoption of this static scheme brought an actual construction effectiveness, on the structural level this scheme proves to be, today, completely devoid of the recent concept of 'structural strength' [24].

In addition to the types mentioned, the Gerber girders were even adopted for special works, such as the bridges designed by the engineer Riccardo Morandi (1902-89). In his research on 'balanced structural systems' Morandi relied on this bridge typology several times. This bridge typology was used for both the project of articulated girders on multiple supports - as in the case of the Quercia-Setta viaduct on the Autostrada del Sole (1957-58) that also featured prefabrication of the elements forming the suspended span [25] - and the conception of special schemes, such as the cable-stayed bridges (i.e. the existing Carpineto viaduct (1976) on the Basentana road [26]).

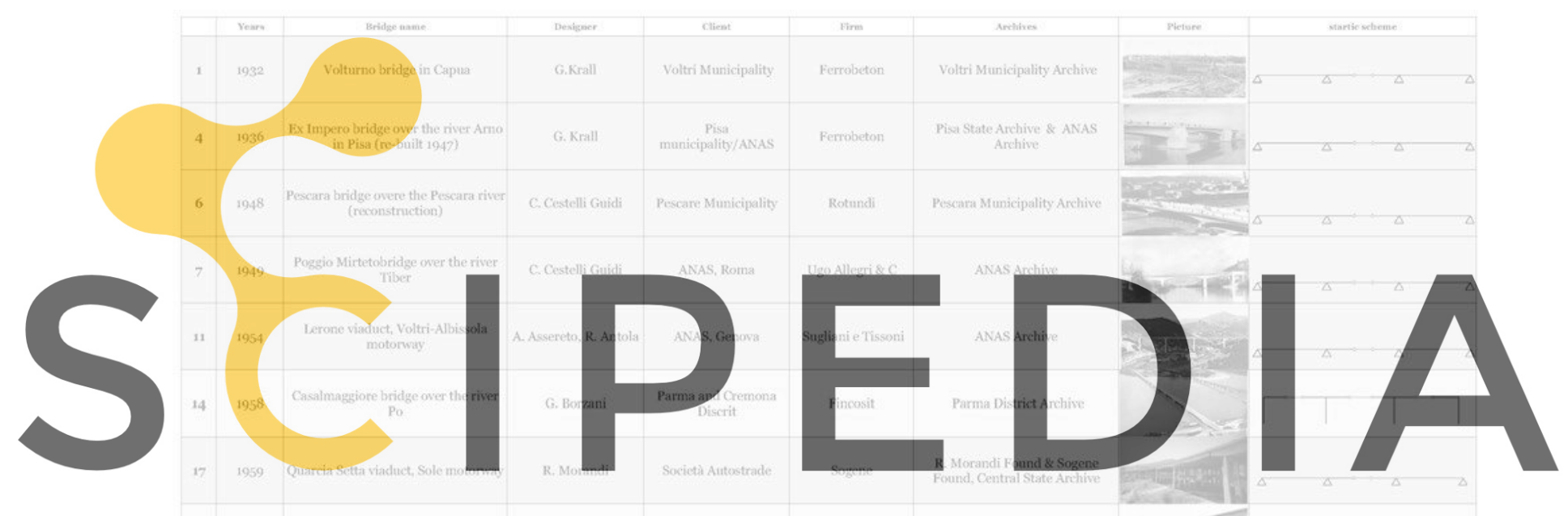

Register for free at https//www.scipedia.com to download the version without the watermark

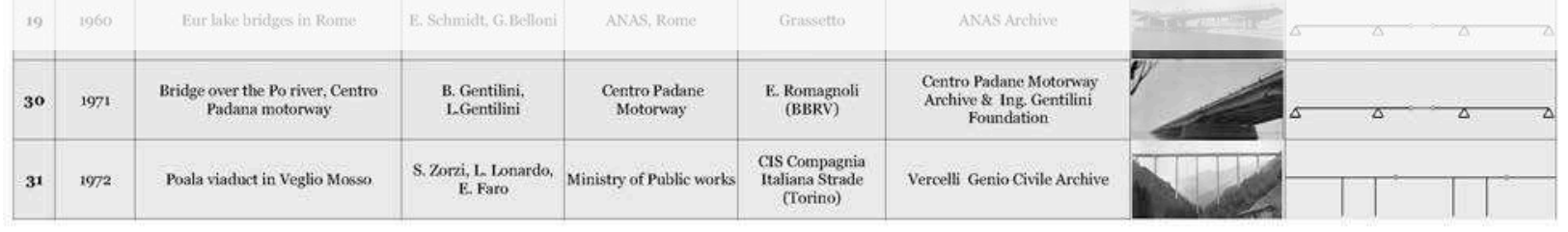

Figure 3: Table extracted from the census of Gerber bridges in Italy

\subsection{Detected common aging and deterioration phenomena}

The whole stock of existing Gerber bridges in Italy feature numerous aging-related decay phenomena. If, most of them are common issues for reinforced concrete structures, such as the natural aging of the materials and the phenomena of carbonation, others are, instead, specifically related to the Gerber bridge half-joint shape. In particular, in Italy, most detected phenomena [27] are leakage of water through the joint causing deterioration of the concrete and corrosion of the reinforcing steel, as it was detected in the Magliana and the Marconi 
bridges in Rome (Fig. 4) and errors during execution, such as misalignment between the cantilever extremes.
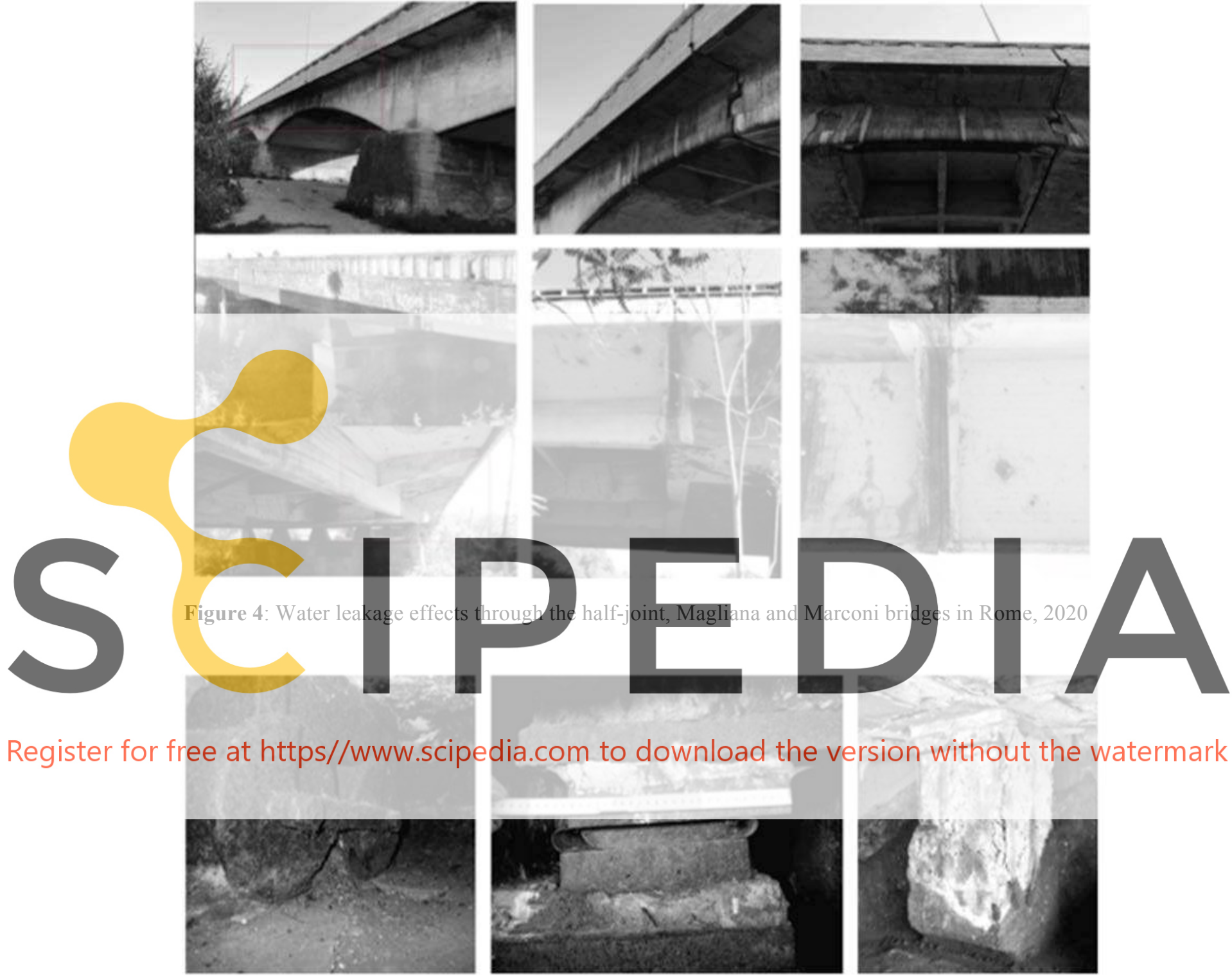

Register for

Figure 5: Metallic support device of Magliana bridges during maintenance operation [28] and reinforced concrete pendulum of Faenza Gerber bridge [29]

Furthermore, even the half-joint equipment, placed on the protruding nib of the structural element, are particularly subject to premature aging, causing dangerous discontinuities in the road surface that, due to even contained disruption, alter driving comfort. In this joint deterioration phenomena framework, it is, thus, necessary to understand how the Gerber halfjoint equipment were built in Italy and whether it is possible to trace the adoption of some recurrent details or solutions. In executive practice, indeed, the use of metal devices (hinges, 
pendulums, rollers) [28], derived from metallic construction practices, was combined with the extensive use of lead sheets, steel plates and the design of the special reinforced concrete pendulums devices, such the one showed in Figure 5 [29].

\section{THE HISTORICAL SOURCES}

Historical data for the 'knowledge phase' of an accurate safety assessment of existing heritage structures requires specific sources. Construction history discipline traditional sources, ranging from primary archival sources to the technical literature of the time period, fit this research purpose [30]. In this investigation framework, the reinforced concrete bridges in Italy, built between 1930s and 1970s feature specific archival sources, that reflected the Institutional framework of the administration charged for the road bridge construction, and specific technical literature, such as bridge design manuals $[12,13,17,20]$ and calculation code.
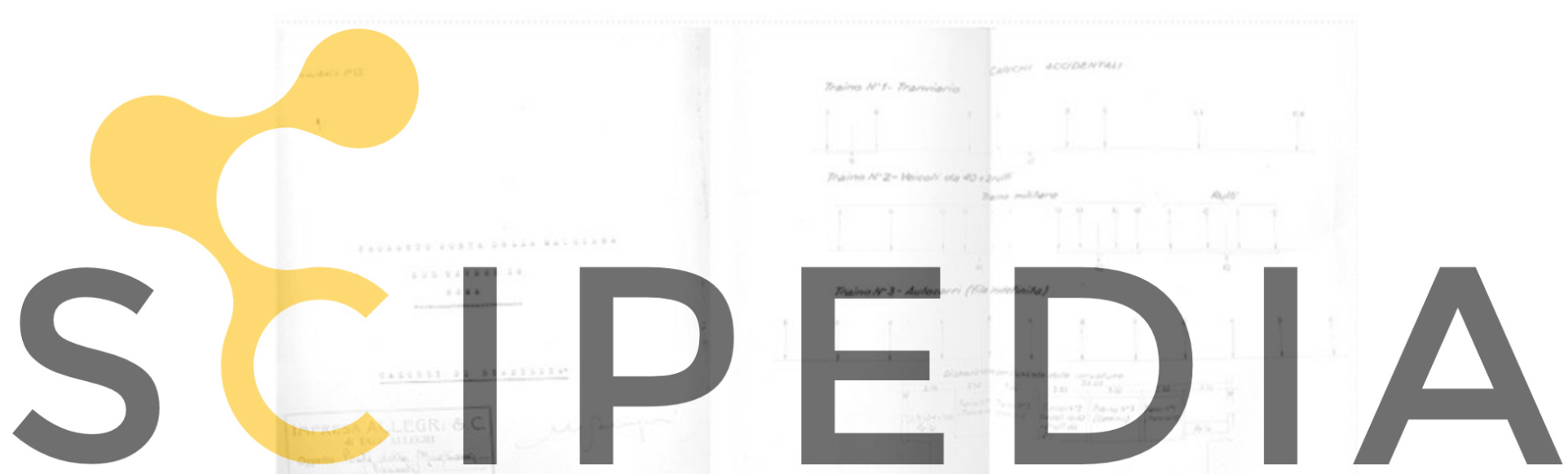

Register for free at https//www.scipedia.com to download the version without the watermark Figure 6: Load pattern considered in the calculation of the Magliana bridge in Rome, 1939 (Courtesy of Rome

State Archive)

\subsection{The archival documentation}

Archival documentation represents the base source to acquire strong knowledge of the original design. In particular, through original design drawings is possible to find the actual geometry and dimensions of the structural elements and of the reinforcement of the halfjoints. Furthermore, through original design reports it is possible to find the adopted calculation, embedding the code regulation of the time period, mechanical characteristic of the employed material and load test results. For example, for the investigated Magliana bridge in Roma (1938-50), through the archival documentation it was possible to extract data relating to the mechanical properties of materials, the load pattern embedded in the original calculations, as reported in Figure 6 and reinforcements geometry and dimensioning, as shown in Figure 7 and Figure 8. Within archival documentation, a crucial source is represented by the construction-site photography. Indeed, through construction-site photos, as 
shown in Figure 8, the design drawings data can be verified, thus providing accurate information about both the built construction details, and the adopted construction processes.

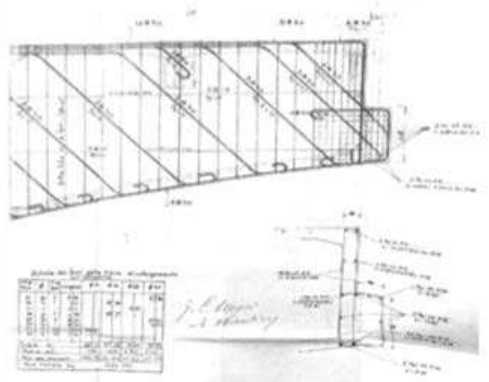

Original design reinforcement detail, 1940

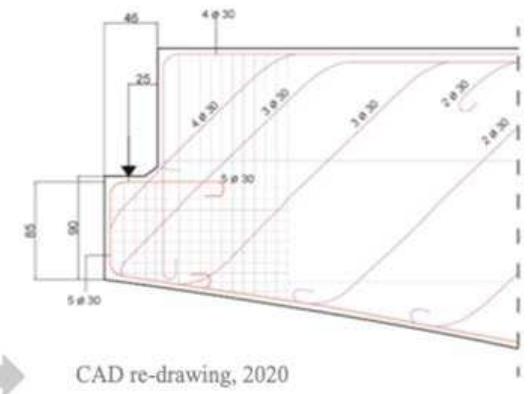

CAD re-drawing, 2020

Figure 7: Reinforcement arrangement and dimensional detail of the Magliana bridge in Rome, 1940(Courtesy of the Rome State Archive), reinforcement CAD redrawing by F. Di Stefano, 2020

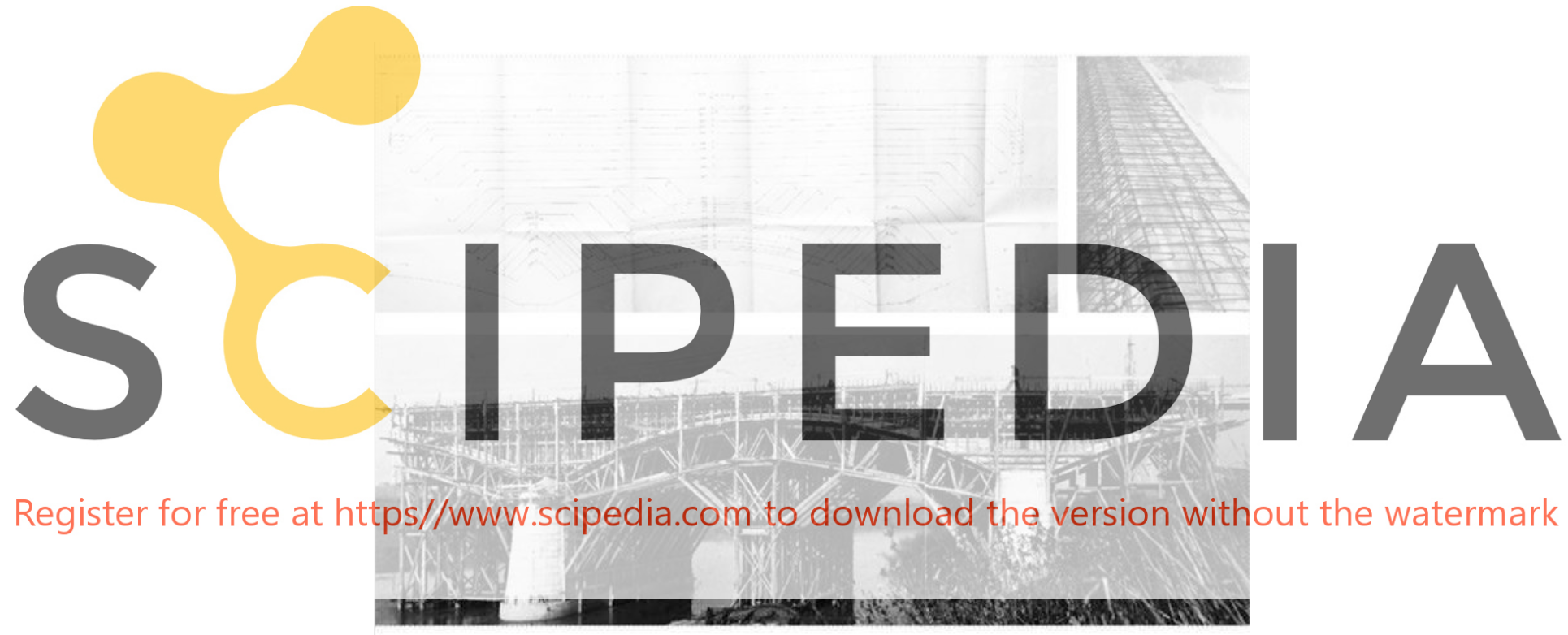

Figure 8: Reinforcement arrangement and dimensional detail of the Magliana bridge in Rome and construction site picture of the same bridge, 1940-43 (Courtesy of the Rome State Archive)

\subsection{The bridge design and calculation manuals and code}

Bridge design and calculation manuals represent the base documentation to understand the evolution of the calculation models of this bridge typology over the different period of their major diffusion. In particular, Albenga manual published in 1930 [12] represent the first treaty dedicated to the calculation of this bridge typology, as explained in paragraph 2.1.

For a proper safety assessment of Gerber bridges, useful information regarding load patterns considered in the original calculations can be derived by past codes. The Circolare n.8, September 15th, 1933 of the High Council of the Italian Ministry of Public Works [31], classifying the road network in three categories depending on the traffic flow, provided three elementary loading patterns: an indefinite column composed by 12 tonne trucks, a 18 tonne 
road roller and a column made up vehicles up to 40 tonne (Fig. 9). These last had to be differently combined, depending on the category of the road, according to the schemes reported in Figure 10.

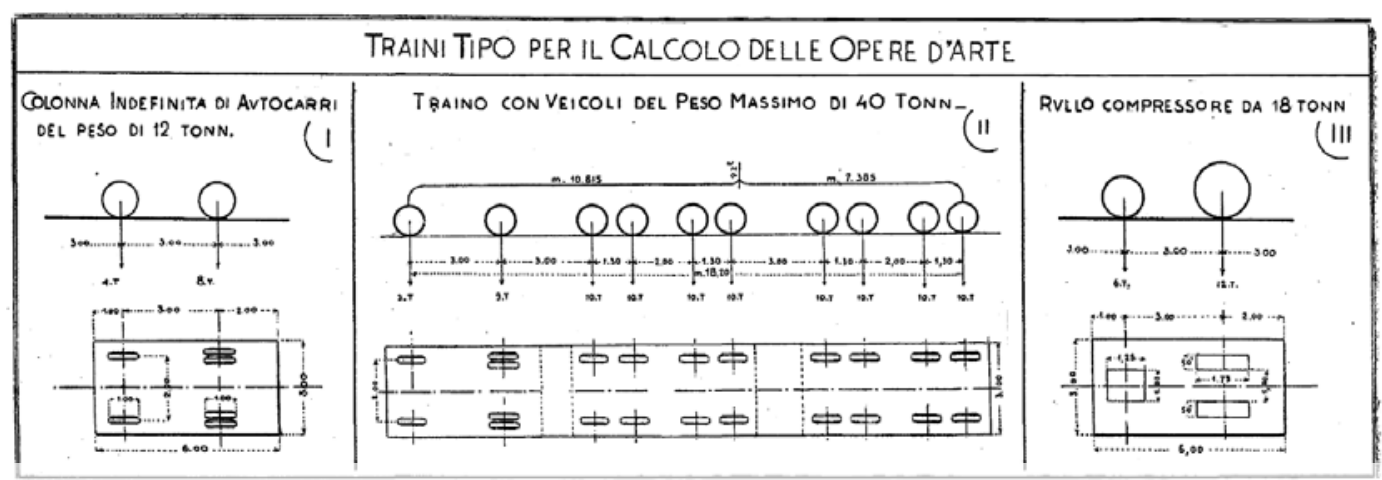

Figure 9: Load patterns from Circolare M.LL.PP. n.8, September 15th, 1933 [31]
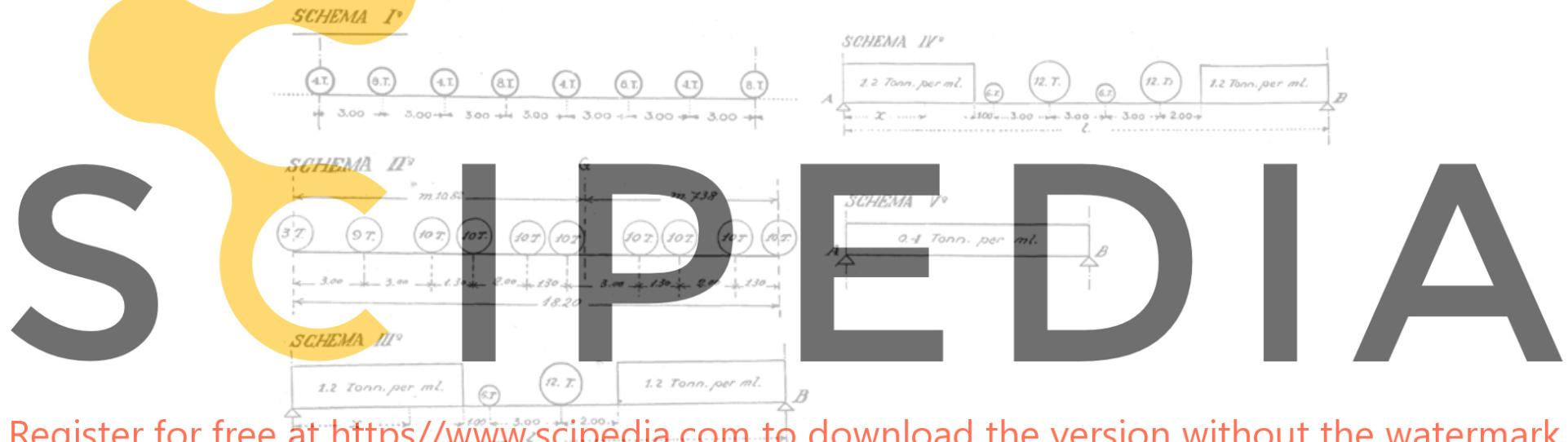

Register for free at https//NwW:Scipedia.com to download the version without the watermark

Figure 10: Load schemes from Circolare M.LL.PP. n.8, September 15th, 1933 [31]

Subsequently, with the Circolare n.6018, June 9th, 1945 of the High Council of the Italian Ministry of Public Works [32], the Italian road network was classified in the two categories of high and low/medium traffic flow roads, for which the following load patterns (Fig. 11) and schemes (Fig. 12) had to be adopted in the calculation phase.
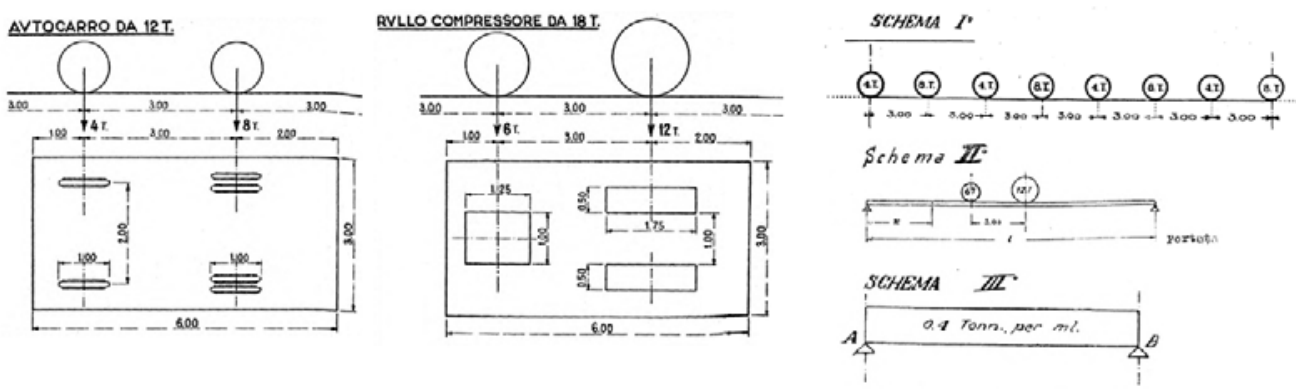

Figure 11: Load schemes and patterns from Circolare M.LL.PP. n.6018, June 9th, 1945 [32] 
Finally, aiming to account for the flow of military vehicles, the Circolare n.384, February 14th, 1962 of the High Council of the Italian Ministry of Public Works [33] divided the road network in first category roads, intended for the flow of civil and military vehicles, and in second category roads, in which civil vehicles only were allowed. New load patterns were introduced to this end, including 61.5, 32 and 74.5 tonne military vehicles (Figure 13).

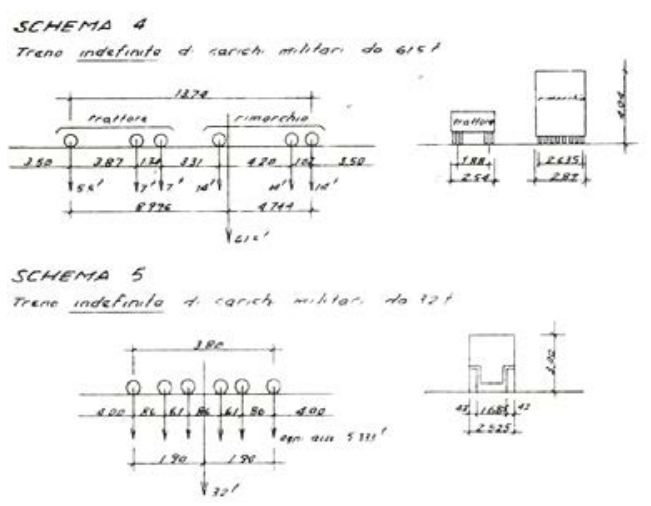

SCHEMA 6
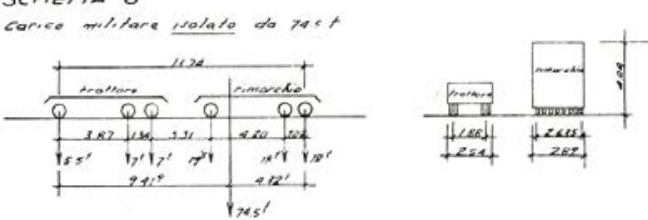

Figure 12: Load patterns from Circolare M.LL.PP. n.384, February 14th, 1962 [33]

\section{CONCLUSIONS}

Among all reinforced concrete bridges' structural typologies, it is worth to count the Gerber bridge, whose diffusion in Italy dates to the years 1930-1970, concurrently with the urgency of the reconstruction after WWII and the development of the national road network between the 1950s and 1960s. Nowadays the need for the safety assessment and structural maintenance of Gerber bridges is fundamental, due to joints which do not comply with current codes and to the occurrence of aging-related decay phenomena. In this framework, a great contribution to the 'knowledge phase' of the entire process of the assessment analysis can result from construction history investigations. In this direction, the paper outlines the history of this particular structural typology, from its introduction and diffusion along the Italian road network, together with a description of the main historical sources at the disposal of engineers called to carry out a crucial role in this context.

Acknowledgments. Researches are supported by the University of Rome "Tor Vergata" Research Grant n. E84I19002380005, project "EpoCA” (P.I. Zila Rinaldi)

\section{REFERENCES}

[1] Norme Tecniche CNR 10037/86, 1992 / EN 1992-1-2:2004

[2] Desnerck, P., Lees, J.M. and Morely, C.T. Reinforcement Layout Implications for Reinforced Concrete Half-Joint Structures, Proceedings of the fib Symposium 2016

[3] Linee guida per la classificazione e gestione del rischio, la valutazione della sicurezza ed il monitoraggio dei ponti esistenti. C.S.LL.PP. (2020).

[4] Steimann, D.B. A Mathematical Study of Cantilever Bridge Design. Vancouver: Read books (2011).

[5] Di Pasquale, S. L'arte del Costruire - Tra conoscenza e scienza. Venezia, Marsilio (1996). 
[6] Mehrtens, L. A hundered years of German bridge building. Berlin, Julius Springer (1900).

[7] Panetti, M. Le costruzioni metalliche moderne nei loro recenti progressi. Ingegneria e Arti Industriali, 22 (1900).

[8] Timoshenko, S. Strenght of Materials. Toronto: D. Van Nostrand Company, (1983).

[9] Wilcox, RM. Theory and Calcultaion on Cantilever bridges. New York. D. Van Nostrand Company, (1898).

[10] Gerber, H. Balkenträger mit freiliegenden Stützpunkten, patent filed 6th December 1866

[11] Colombo, G. Manuale dell'ingegnere. Milano, Hoepli, (1877).

[12] Jorini, A.F. Teoria e pratica della costruzione dei ponti. Milano, Hoepli, (1905).

[13] Albenga, G. Lezioni di Ponti. Milano, Hoepli, (1930).

[14] Santarella, L. and Miozzi, E. Ponti Italiani in cemento armato. Milano, Hoepli (1924).

[15] Santarella, L. and Miozzi, E. Ponti Italiani in cemento armato. Milano, Hoepli (1932).

[16] Ferrobeton, Impresa Generale di Costruzioni, 1908 - 1933. Catalogo, Roma, (1933).

[17] Albenga, G. Lezioni di ponti. La Pratica. Milano, Hoepli, (1953).

[18] Krall, G. Un nuovo ponte sull'Arno a Pisa. Ind. Italiana del cemento (1937) 4:112-123.

[19] Albenga, G. Lezioni di ponti. La Teoria. Milano, Hoepli (1958).

[20] Rinaldi, G. La costruzione dei ponti. Roma, Editrice Eredi (1974).

[21] Gentilini, B. and Gentilini, L. Viadotto del colle Isarco nel tratto Brennero-Cave dell'Autostrada del Brennero. In Realizzazioni italiane in cemento armato precompresso, VI congresso FIP, 180-185, Roma, AITEC (1970).

[22] Zorzi, S. Viadotto sul torrente Stura, Autostrada Torino-Savona. In Realizzazioni italiane in cemento armato precompresso, VI congresso FIP, 58-63, Roma, AITEC (1970).

[23] Zorzi, S. Viadotto sul torrente Poala a Veglio Mosso. In Realizzazioni italiane in cemento armato precompresso, VII congresso FIP, 56-59. Roma, AITEC (1974).

[24] D.M. 17 gennaio 2018, Aggiornamento delle "Norme tecniche per le costruzioni".

[25] Morandi, R. Viadotto Quercia Setta Autostrada del Sole. In Costruzioni in Cemento Armato. Studi e Rendiconti, 176-77. Milano Politecnico, Italcementi (1967).

[26] Morandi, R. Il viadotto Carpineto 1 per le strade di grande comunicazione Basentana. Industria Italiana del Cemento, (1977) 10: 817-830.

[27] Malerba, P.G. Ponti articolati e continui: 150 anni di esperienze, seconda parte. Una approfondita analisi dell'evoluzione delle principali tipologie dei ponti Gerber e Cantilever. Strade e autostrade, (2018) 131: 60-63.

[28] Lavori di manutenzione straordinaria del ponte e viadotto della magliana, Relazione Descrittiva Generale, 6/12/2018 https://romacapitale.tuttogare.it/gare/id2859-dettaglio

[29] Micheloni, M., La Monica, M., Parmeggiani, D. and Barchi, P. Sustainable structural rehabilitation and strengthening of the "Ponte delle Grazie" bridge in Faenza. IOP Conf. Series: Materials Science and Engineering (2018) 442:012021.

[30] Pelke, E. and Brühwiler, E. Engineering History and Heritage Structures - Viewpoints and Approaches. Zurich, IABSE (2017).

[31] Circ. M.LL.PP. n.8, 15 settembre 1933, Carichi da considerare nel calcolo dei ponti per strade ordinari.

[32] Circ. M.LL.PP. n.6018, 9 giugno 1945, Carichi da considerare nel calcolo dei ponti per strade ordinari.

[33] Circ. M.LL.PP. n.384, 14 febbraio 1962, Nome relative ai carichi per i ponti stradali. 